\title{
Feeding habits of Lithobates megapoda (Anura: Ranidae), a threatened leopard frog used for human consumption, in Lake Chapala, Mexico
}

\author{
José Luis Barragán-Ramírez, ${ }^{1}$ Benjamín Hernández, ${ }^{2}$ María Guadalupe Velarde-Aguilar, ${ }^{3}$ \\ Oscar Pérez-Flores, ${ }^{3}$ José Luis Navarrete-Heredia, ${ }^{1}$ and Eduardo Pineda ${ }^{4}$ \\ ${ }^{1}$ Universidad de Guadalajara, Centro de Estudios en Zoología - CUCBA. Apartado postal 134, 45100 Zapopan, Jalisco, \\ Mexico. E-mail: jslsbarragn@gmail.com. \\ ${ }^{2}$ Tecnológico Nacional de México, Instituto Tecnológico de Tlajomulco. Departamento de Ciencias Básicas. Carretera \\ Tlajomulco-San Miguel Cuyutlán Km. 10, C.P. 45640, Tlajomulco de Zúñiga, Jalisco, Mexico. \\ ${ }^{3}$ Universidad Nacional Autónoma de México, Instituto de Biología, Colección Nacional de Insectos. Av. Universidad 3000 , \\ Delegación Coyoacán, C.P. 04510. Distrito Federal, Mexico. \\ ${ }^{4}$ Instituto de Ecología, Red de Biología y Conservación de Vertebrados. A.C., Xalapa, C.P. 91073, Veracruz, Mexico. \\ E-mail: eduardo.pineda@inecol.mx.
}

\begin{abstract}
Feeding habits of Lithobates megapoda (Anura: Ranidae), a threatened leopard frog used for human consumption, in Lake Chapala, Mexico. The Big-footed Leopard Frog (Lithobates megapoda) is a threatened and endemic species from western Mexico. This species has aquatic habits and it is distinguished by its large size, particularly by the length of its legs, reason for which it is captured for human consumption. Also, knowledge about its natural history is scarce and incomplete. In this study, we analyzed the composition of the diet of L. megapoda on the shore of Lake Chapala, the largest lake in Mexico. A total of 69 adult individuals were collected lifeless in fishing nets, during the rainy season (JuneOctober), of which 48 had stomach contents. A total of 96 prey items were identified, which correspond to 13 prey categories. Fish constituted the most dominant prey category in the diet in terms of number, volume, frequency of occurrence, and relative importance. No significant differences were found in the consumption by prey type (aquatic or terrestrial). However, the aquatic preys had a greater relative importance and were more voluminous than the terrestrial ones. The diversity of prey categories, in terms of prey volume, indicates males may have a higher dietary diversity than females, but we not evaluated possible bias. In addition, a significant effect was found in the interaction of size (SVL) of frogs with the average of prey volume. Females (that are larger than males) consumed prey within a wide volume range and, the larger they are, more voluminous are prey. In this way it is possible that intraspecific competition for trophic resources in the environment is reduced. This study helps us understand the trophic ecology of L. megapoda, a frog species that plays an important role in the food web where it lives, as a predator feeding on aquatic and terrestrial organisms.
\end{abstract}

Keywords: Amphibians, diet, fish, intersexual variation, trophic ecology.

Received 27 March 2020

Accepted 15 June 2021

Distributed June 2021 


\title{
Resumen
}

Hábitos alimenticios de Lithobates megapoda (Anura: Ranidae), una rana leopardo amenazada utilizada para consumo humano, en el Lago de Chapala, México. La rana patona (Lithobates megapoda) es una especie endémica y amenazada del occidente de México. Esta especie es de hábitos acuáticos y se caracteriza por su gran tamaño, particularmente por la longitud de sus ancas, razón por la cual es capturada para consumo humano. Además, el conocimiento sobre su historia natural es escaso e incompleto. En este estudio, se analizó la composición de la dieta de L. megapoda en las inmediaciones del Lago de Chapala, el lago más grande de México. Un total de 69 individuos adultos fueron recolectados sin vida en redes de pesca, durante la época de lluvias (junio-octubre), de los cuales 48 tuvieron contenido estomacal. En total se identificaron 96 presas, las cuales corresponden a 13 categorías de presa. Los peces constituyeron la categoría más valiosa en la dieta en cuanto a número, volumen, frecuencia de ocurrencia e importancia relativa. No se encontraron diferencias significativas en el consumo por tipo de presa (acuática o terrestre). Sin embargo, las presas acuáticas tuvieron mayor importancia relativa y fueron más voluminosas que las terrestres. La diversidad de categorías de presa, en términos de volumen de presa, indica que los machos pueden tener una mayor diversidad dietaría que las hembras, pero no evaluamos un posible sesgo. Además, se encontró un efecto significativo en la interacción del tamaño (SVL) de las ranas con el volumen promedio de presa. Las hembras (más grandes que los machos) consumieron presas dentro de un rango de volumen amplio y, entre más grandes son, más voluminosas son las presas. De esta forma es posible que se reduzca la competencia intraespecífica por los recursos tróficos en el ambiente. Este estudio nos permite comprender la ecología trófica de L. megapoda, una especie que juega un papel importante en la red alimenticia donde vive, como depredador de organismos acuáticos y terrestres.

Palabras clave: anfibios, dieta, ecología trófica, peces, variación intersexual.

\begin{abstract}
Resumo
Hábitos alimentares de Lithobates megapoda (Anura: Ranidae), uma rã-leopardo ameaçada utilizada para consumo humano, no Lago Chapala, México. A rã-leopardo-de-pés-grandes (Lithobates megapoda) é uma espécie ameaçada e endémica do México ocidental. Essa espécie tem hábitos aquáticos e distingue-se pelo seu grande tamanho, particularmente pelo comprimento das patas, razão pela qual é capturada para consumo humano. Além disso, o conhecimento sobre sua história natural é escasso e incompleto. Neste estudo, analisamos a composição da dieta de $L$. megapoda nas margens do Lago Chapala, o maior lago do México. Um total de 69 indivíduos adultos foram coletados mortos em redes de pesca durante a época das chuvas (Junho-Outubro), dos quais 48 apresentravam conteúdo estomacal. Foi identificado um total de 96 itens, o que corresponde a 13 categorias de presas. Os peixes constituíram a categoria de presas mais dominante na dieta em termos de número, volume, frequência de ocorrência e importância relativa. Não foram encontradas diferenças significativas no consumo por tipo de presa (aquática ou terrestre). No entanto, as presas aquáticas apresentaram maior importância relativa e eram mais volumosas que as terrestres. A diversidade de categorias de presas, em termos de volume de presas, indica que os machos podem exibir uma maior diversidade alimentar do que as fêmeas, mas não avaliamos possíveis vieses. Além disso, foi encontrado um efeito significativo na interacção do tamanho (SVL) das rãs com a média do volume de presas. As fêmeas (que são maiores do que os machos) consumiram presas dentro de uma vasta gama de volumes, e quanto maiores, mais volumosas as presas. Dessa forma, é possível que a competição intraespecífica por recursos alimentares no ambiente seja reduzida. Este estudo ajuda-nos a compreender a ecologia trófica de L. megapoda, uma espécie de anuro que desempenha um papel importante na teia alimentar do ambiente em que vive, como predador que se alimenta de organismos aquáticos e terrestres.
\end{abstract}

Palavras-chave: anfíbios, dieta, ecologia trófica, peixes, variação intersexual. 


\section{Introduction}

Amphibians, particularly anurans, are an important component of the trophic structure of ecosystems because they are abundant, show high biomass (Gibbons et al. 2006), and constitute a link between aquatic and terrestrial communities (Stebbins and Cohen 1995, Duré et al. 2009), acting both as predators (e.g., LuríaManzano and Ramírez-Bautista 2017, 2019) and as preys of a wide variety of organisms (e.g., Fulgence et al. 2020, Nuñez-Escalante and Garro-Acuña 2021). Therefore, knowing the feeding habits of anurans help us to understand their role on the energy flow and on the interactions of the food webs in which they are involved (Duellman and Trueb 1994, LuríaManzano and Ramírez-Bautista 2017). Besides ecological importance, dietary aspects of anurans may have implications for conservation. For example, knowledge of dietary diversity is necessary to detect those species with narrow trophic niches, which are potentially vulnerable to changes in the structure of the prey community they consume (Luría-Manzano and RamírezBautista 2019).

Most anurans are considered generalist consumers because they feed on a wide prey range (Duellman and Trueb 1994, Solé and Rödder 2010). However, there is evidence that some of them have a narrow diet, showing a specialized consumption on certain biological groups (Agudelo-Cantero et al. 2015, Lopes et al. 2017, Araujo-Vieira et al. 2018). Differences in the diet composition have been related to different factors, which may be extrinsic, such as the site traits (Bonansea and Vaira 2007), competition (Duellman and Trueb 1994), or seasonality (Berazategui et al. 2007), which can offer different food resources, or intrinsic factors, such as ontogenetic changes (Whitfield and Donnelly 2006), reproductive behavior, and sex (Lamb 1984, Maneyro et al. 2004), which influence the nutritional requirements of anurans. Both extrinsic and intrinsic factors are related to the use of food resources and the variation in the diet composition between and within species (Lima and Magnusson 2000).

Lithobates megapoda (Taylor, 1942), commonly known as Big-footed Leopard Frog (Liner and Casas-Andreu 2008), is an endemic anuran species to western Mexico in the states of Nayarit, Jalisco, Guanajuato, and Michoacán (Webb 1996). Its large body size, with females reaching a snout-vent length of up to $157 \mathrm{~mm}$ (Webb 1996) and males of up to $117 \mathrm{~mm}$ (Taylor and Smith 1945), makes this species one of the largest anurans in Mexico. This frog is predominantly aquatic and inhabits and breeds in perennial water sources, in shrubland and pineoak forest from 823 to $1,520 \mathrm{~m}$ a.s.l. (IUCN SSC Amphibian Specialist Group 2020). In addition, this species is threatened mainly due to habitat destruction and degradation, water pollution, droughts due to climate change, introduction of exotic species (IUCN SSC Amphibian Specialist Group 2020), and extraction for human consumption (Barragán-Ramírez et al. 2017, IUCN SSC Amphibian Specialist Group 2020). These impacts have led to this frog being currently protected by Mexican law NOM-059SEMARNAT-2010 under the Special Protection category (Pr) (SEMARNAT 2010) and considered as Near Threatened by the IUCN (IUCN SSC Amphibian Specialist Group 2020). Despite this, basic information about its natural history is scarce.

In this study, we evaluated dietary composition of adult individuals of L. megapoda on the shore of Lake Chapala.

\section{Materials and Methods}

\section{Study Site}

Lake Chapala is the largest and most important lake in Mexico, it is located between the boundaries of the states of Jalisco and Michoacan $\left(20^{\circ} 14^{\prime} \mathrm{N}, 103^{\circ} 00^{\prime} \mathrm{W}\right.$, elevation 1,524 $\mathrm{m}$ a.s.l., Figure 1). It has a surface area of 1,146 $\mathrm{km}^{2}$ (28 km from north to south and $79 \mathrm{~km}$ from east to west), a maximum storage capacity of 


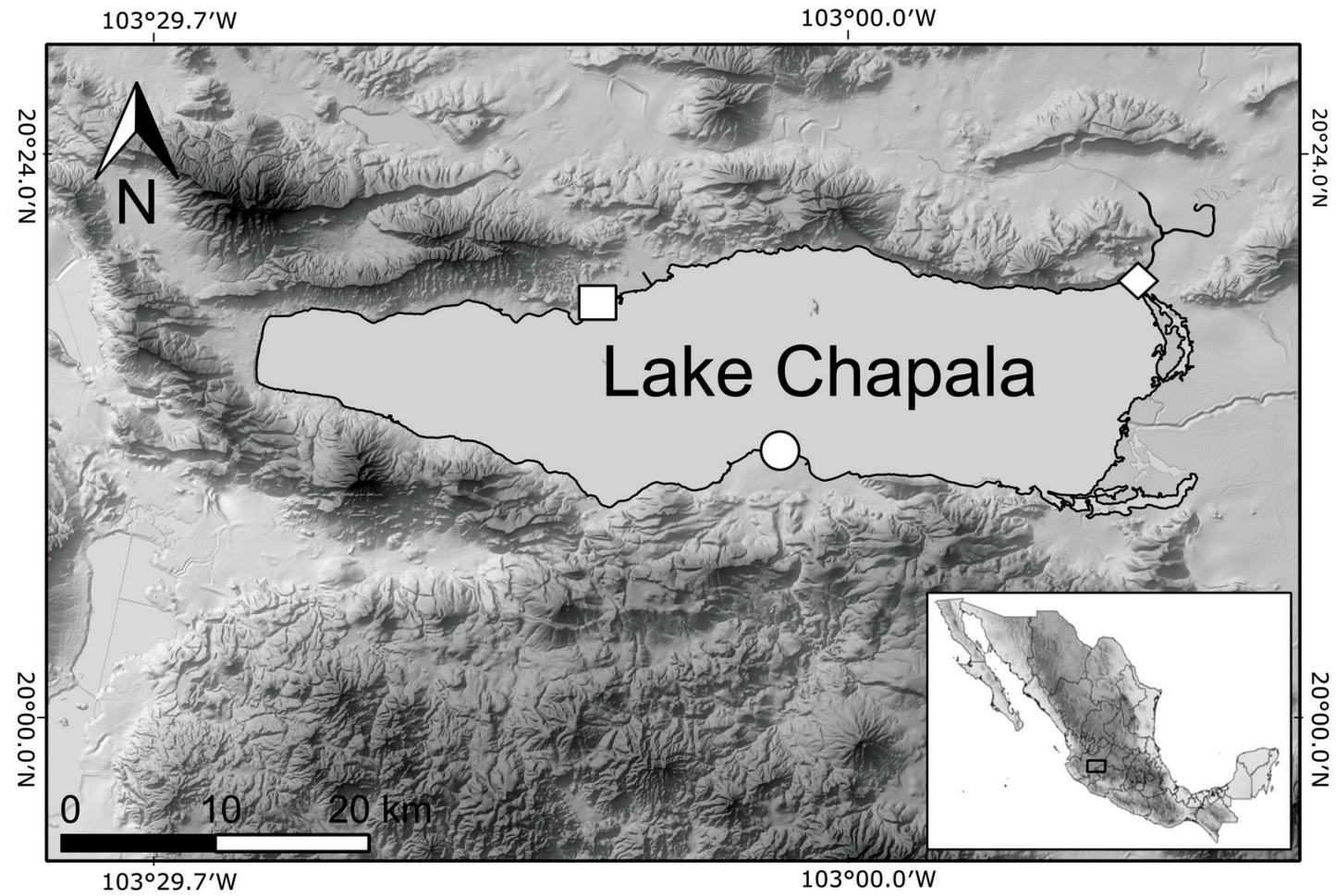

Figure 1. Map showing the sampled areas of Chapala (square), Tizapan El Alto (circle) and Ocotlan (diamond) along the Lake Chapala, state of Jalisco, Mexico.

$7,897 \mathrm{~m}^{3}$ and a maximum of $8 \mathrm{~m}$ of depth (CEA Jalisco 2020). Mean annual temperature in the region is $19.9^{\circ} \mathrm{C}$ and varies from 9 to $30^{\circ} \mathrm{C}$. Annual rainfall is estimated at $735 \mathrm{~mm}$ (Filonov et al. 2001), with most rains occurring between June and September.

\section{Data Collection}

Sixty-nine adult individuals of Lithobates megapoda were examined for the present study. All individuals were found dead in fishing nets during the rainy season (June-October) in different years. Eleven frogs were collected in Ocotlán $\left(20^{\circ} 19^{\prime} 06^{\prime \prime} \mathrm{N}, 102^{\circ} 47^{\prime} 20^{\prime \prime} \mathrm{W}\right)$ between September-October 2020; forty-seven frogs collected in the vicinity of Chapala $\left(20^{\circ} 17^{\prime} 38^{\prime \prime} \mathrm{N}\right.$, $103^{\circ} 10^{\prime} 40^{\prime \prime}$ W) between June and October 2016, and the rest of the individuals were captured between June and September 2015: seven in Tizapán El Alto $\left(20^{\circ} 09^{\prime} 04^{\prime \prime} \mathrm{N}, 103^{\circ} 02^{\prime} 48^{\prime \prime} \mathrm{W}\right)$ and four from Ocotlán (Figure 1). All frogs were collected using a special permit SGPA/ DGVS/03444/15 issued by Mexican Ministry of Environment (Secretaría de Medio Ambiente y Recursos Naturales). Specimens were fixed in $10 \%$ formalin solution and preserved in $70 \%$ alcohol after data collection and deposited in a vertebrate scientific collection at Centro de Estudios en Zoología, Universidad de Guadalajara (CZUG).

Each individual was measured, weighed and its sex was identified. A Mitutoyo ${ }^{\circledR}$ digital caliper was used to record snout-vent length 
(SVL) (to the nearest $0.01 \mathrm{~mm}$ ). Body mass was measured using an Ohaus ${ }^{\circledR}$ digital balance $( \pm$ $0.1 \mathrm{~g}$ of accuracy). Values are presented as mean \pm standard deviation (SD). Maturity and sex of individuals were determined either by secondary sexual characters (presence of vocal sacs and nuptial pads in males; absent in females) or by gonadal identification after dissection. We removed the stomach of each individual and the content was placed in a Petri-dish and examined under a stereomicroscope (ZEISS Stemi DV4). Prey items were classified taxonomically to the Order level (prey category) using the keys of Coronado and Márquez (1977) and Triplehorn and Johnson (2005); when possible, items were identified to the genus and/or species level. Only in vertebrate prey, taxonomic Class level is equal to "prey category". Later, we counted and classified each prey according to its habits: aquatic or terrestrial. Prey volume was estimated by fluid displacement to the nearest $0.1 \mathrm{~mL}$ (Magnusson et al. 2003). Subsequently, the units in $\mathrm{mL}$ were converted to $\mathrm{cm}^{3}$. Stomach contents were preserved in $70 \%$ ethanol and stored in the entomological collection at Centro de Estudios en Zoología of the Universidad de Guadalajara (CZUG). Furthermore, those prey items that were too fragmented or that could not be identified due to advanced stage of digestion, were included in the "undetermined remains" category.

\section{Data Analyses}

In order to determine the contribution of each prey category, we calculated an index of relative importance using the following formula $\mathrm{I}=(\mathrm{F} \%$ $+\mathrm{N} \%+\mathrm{V} \%) / 3$, where $\mathrm{F} \%, \mathrm{~N} \%$ and $\mathrm{V} \%$ are the percentages of frequency, number of prey and prey volume, respectively (Biavati et al. 2004). Differences in consumption per prey type (aquatic vs. terrestrial) and volume of prey consumed were analyzed with Mann-Whitney U-test. To determine differences in diet composition between the sexes by prey categories in terms of abundance and volume prey, we constructed contingency tables and a chi-square test $\left(\chi^{2}\right)$ was applied.

Diet diversity was estimated with the Shannon index (Shannon and Weaver 1949) using the number of items and volume of each prey category as diversity attributes: $\mathrm{H}^{\prime}=-\sum_{i=1}^{S} p_{i} \ln p_{i}$, where $p_{i}$ is the proportion of the resource $i$ (prey category) in the diet and $S$ is the total number of prey categories. The exponential to Shannon's diversity values was calculated in order to represent the results in terms of effective species number (true diversity), sensu Jost (2006) : ${ }^{1} D=$ $\exp \left(\mathrm{H}^{\prime}\right)$, where ${ }^{1} D$ represented the dietary diversity observed $\left({ }^{1} D_{o b s}\right)$. Additionally, we estimated dietary diversity $\left({ }^{1} D_{\text {ess }}\right)$ with a Jacknife estimator (Zahl 1977) and statistically compared it among sexes by calculating 95\% confidence intervals.

The relationship SVL-average of prey volume, SVL-total prey volume, and SVL-prey number were analyzed under a Covariance Analysis structure (ANCOVA) where a Generalized Linear Model (GLM) was used with a Gamma distribution as error and a square-root link function. Volume and prey number were selected as dependent variables and the sex as covariate. All statistical analyses were performed using R software (R Core Team 2017).

\section{Results}

\section{Diet Composition}

We obtained 69 adult individuals of Lithobates megapoda, 40 females and 29 males. Females had a snout-vent length (SVL) of $123.30 \pm 18.52 \mathrm{~mm}$ and a body mass of $289.0 \pm$ $118.4 \mathrm{~g}$. Males had a SVL of $96.67 \pm 9.33 \mathrm{~mm}$ and body mass $132.7 \pm 35.1$ g. Females were larger (Mann-Whitney $\mathrm{U}=458, p<0.001$ ) and heavier (Mann-Whitney $\mathrm{U}=382, p<0.001$ ) than males, with more than twice the mass of males on average (Table 1).

A total of 48 individuals had stomach content (29 females and 19 males); 42 with at least one identifiable prey item and six with only plant 
Table 1. Snout-vent length (SVL), body mass and dietary parameters for females and males of Lithobates megapoda.

\begin{tabular}{lcccc}
\hline & \multicolumn{1}{c}{ Females } & \multicolumn{2}{c}{ Males } \\
\cline { 2 - 5 } & Mean \pm SD (range) & $N$ & Mean \pm SD (range) & $N$ \\
\hline SVL $(\mathrm{mm})$ & $123.30 \pm 18.52(77.10-150.88)$ & 40 & $96.67 \pm 9.33(80.02-112.76)$ & 29 \\
Body mass $(\mathrm{g})$ & $289.0 \pm 118.4(57.0-567.0)$ & 40 & $132.7 \pm 35.1(65.0-208.0)$ & 29 \\
Number of prey per stomach & $2.4 \pm 2.0(1-8)$ & 27 & $2.1 \pm 1.9(1-8)$ & 15 \\
Prey volume $\left(\mathrm{cm}^{3}\right)$ & $0.81 \pm 1.41(0.02-7.86)$ & 65 & $0.19 \pm 0.31(0.01-1.52)$ & 31 \\
Stomach content volume $\left(\mathrm{cm}^{3}\right)$ & $2.06 \pm 2.12(0.09-7.86)$ & 29 & $0.57 \pm 0.47(0.03-1.70)$ & 19 \\
\hline
\end{tabular}

material and non-identifiable remains. We identified 96 prey items belonging to 13 prey categories: 11 invertebrates and only two vertebrates (anurans and Actinopterygii fishes) (Table 2). The mean number of prey items per stomach was $2.00 \pm 1.95$ (range 1-8). We found a range of 0.01 to $7.86 \mathrm{~cm}^{3}$ of prey volume per stomach, and a range of 0.03 to $7.86 \mathrm{~cm}^{3}$ of volume of stomach contents. Fish were the most dominant prey category in terms of frequency $(50.1 \%)$, number $(36.5 \%)$ and volume $(57.3 \%)$, which comprised two taxonomic orders: Cyprinodontiformes and Perciformes. Also, this food category was the most important in the diet of $L$. megapoda, $I=48.0$ (Table 2, Figure 2). Araneae was the second most important prey category ( $I$ $=12.5)$ and Hemiptera was the third one $(I=$ 7.8). Plant material and undetermined remains were also part of the diet, these were found in six $(12.5 \%)$ and $25(52.1 \%)$ stomachs and they constitute $2.6 \%$ and $14.3 \%$ of the total volume ingested, respectively (Table 2).

The consumption by prey type, aquatic and terrestrial, comprised $43.8 \%$ and $56.2 \%$ of the total number of prey items, respectively (Table $2)$. Frogs with only identifiable prey items in their stomach $(N=42)$ showed a range of 0-7 terrestrial prey per stomach, followed by a range of 0-5 aquatic prey per stomach, with no differences between the consumption of both prey types (Mann-Whitney $\mathrm{U}=875, p=0.95$ ). Regarding the total volume of ingested prey, aquatic preys (76.4\%) surpassed the terrestrial ones $(23.6 \%)$. The volume range of aquatic prey consumed was $0.04-7.86 \mathrm{~cm}^{3}(N=42)$, while that of the terrestrial prey was $0.01-3.00 \mathrm{~cm}^{3}$ $(N=54)$. Terrestrial preys were smaller (volumetrically) than the aquatic ones (MannWhitney $\mathrm{U}=1868, p<0.001)$. The index of relative importance showed that aquatic preys were more important than terrestrial in the diet of L. megapoda (Table 2).

\section{Diet Variation}

Analyzing the prey consumption data by sex, we found differences in the prey volume (MannWhitney $\mathrm{U}=1542, p=-0.001$ ) and in the volume of stomach content (Mann-Whitney $U=431$, $p=-0.001)$. Females consumed bulky prey and showed a greater volume of stomach content than males (Table 1). Also, we found differences in the numerical $\left(X^{2}=45.95, \mathrm{df}=12, p<0.001\right)$ and volumetric $\left(X^{2}=60.53, \mathrm{df}=12, p<0.001\right)$ proportions of prey categories consumed between the sexes. Fish (Actinopterygii) were the most important prey category in the diet of females $(I=52 \%)$ and males $(I=25.4 \%)$ (Table $3)$. Dietary diversity $\left({ }^{1} \mathrm{D}\right)$ observed and estimated, using the abundance of prey categories, was similar in both sexes (females ${ }^{1} \mathrm{D}_{\text {obs }}=6.68,{ }^{1} \mathrm{D}_{\text {est }}$ $=7.72 ;$ males $\left.{ }^{1} \mathrm{D}_{\text {obs }}=6.68,{ }^{1} \mathrm{D}_{\text {est }}=7.72\right)$. However, when analyzing dietary diversity using prey volume, we found that males show greater diversity $\left({ }^{1} \mathrm{D}_{\text {obs }}=5.23,{ }^{1} \mathrm{D}_{\text {est }}=12.14\right)$ than females $\left({ }^{1} \mathrm{D}_{\text {obs }}=2.81,{ }^{1} \mathrm{D}_{\text {est }}=3.22\right)$ (Figure 3$)$. 
Table 2. Diet composition of Lithobates megapoda $(N=48)$ on the shore of Lake Chapala, Jalisco, Mexico. $N$, Number of individuals; $V$, Prey volume $\left(\mathrm{cm}^{3}\right) ; F$, Frequency of occurrence of each prey item; I, Index of relative importance. *Endemic to Lake Chapala basin and the surrounding area; **Introduced to Lake Chapala.

\begin{tabular}{lccccccccc}
\hline $\begin{array}{l}\text { Taxonomic Class/ } \\
\text { Prey category }\end{array}$ & Prey type & $\mathbf{N}$ & $\mathbf{N} \%$ & $\boldsymbol{F}$ & $\boldsymbol{F} \%$ & $\boldsymbol{V}$ & $\boldsymbol{V} \%$ & $\boldsymbol{I}$ \\
\hline INVERTEBRATES & & & & & & & & \\
Arachnida & & & & & & & & & \\
Araneae & $\mathrm{T}$ & & 6 & 6.3 & 5 & 10.4 & 1.16 & 1.6 & 6.1 \\
$\quad$ Lycosidae & $\mathrm{T}$ & 6 & 6.3 & 4 & 8.3 & 0.26 & 0.4 & 5.0 \\
$\quad$ Tetragnathidae & $\mathrm{T}$ & 2 & 2.1 & 2 & 4.2 & 0.03 & 0.0 & 2.1
\end{tabular}

Opiliones

Sclerosomatidae

$\begin{array}{lllllllll}\text { Leiobunum sp. } & \mathrm{T} & 1 & 1.0 & 1 & 2.1 & 0.10 & 0.1 & 1.1\end{array}$

\section{Diplopoda}

Polydesmida

Paradoxosomatidae

\section{Hexapoda}

Coleoptera

Chrysomelidae

Disonycha sp.

Omophoita sp.

Scarabaeidae

$\begin{array}{lllllllll}\text { Phyllophaga sp. } & \mathrm{T} & 1 & 1.0 & 1 & 2.1 & 0.26 & 0.4 & 1.2 \\ \text { Xyloryctes sp. } & \mathrm{T} & 2 & 2.1 & 2 & 4.2 & 1.13 & 1.6 & 2.6\end{array}$

Staphylinidae

$\begin{array}{ccccccccc}\text { Platydracus sp. } & \mathrm{T} & 1 & 1.0 & 1 & 2.1 & 0.04 & 0.1 & 1.1 \\ \text { Unidentified } & \mathrm{T} & 1 & 1.0 & 1 & 2.1 & 0.10 & 0.1 & 1.1\end{array}$

Dermaptera

Forficulidae

\begin{tabular}{|c|c|c|c|c|c|c|c|c|}
\hline Doru sp. & $\mathrm{T}$ & 9 & 9.4 & 3 & 6.3 & 1.07 & 1.5 & 5.7 \\
\hline Hemiptera & & 6 & 6.3 & 6 & 12.5 & 3.38 & 4.8 & 7.8 \\
\hline Belostomatidae (adult) & A & 2 & 2.1 & 2 & 4.2 & 2.24 & 3.2 & 3.1 \\
\hline Belostomatidae (nymph) & A & 2 & 2.1 & 2 & 4.2 & 0.84 & 1.2 & 2.5 \\
\hline Notonectidae & A & 1 & 1.0 & 1 & 2.1 & 0.10 & 0.1 & 1.1 \\
\hline Unidentified & $\mathrm{T}$ & 1 & 1.0 & 1 & 2.1 & 0.20 & 0.3 & 1.1 \\
\hline Hymenoptera & & 3 & 3.1 & 3 & 6.3 & 0.15 & 0.2 & 3.2 \\
\hline \multicolumn{9}{|l|}{ Apidae } \\
\hline Apis mellifera & $\mathrm{T}$ & 2 & 2.1 & 2 & 4.2 & 0.12 & 0.2 & 2.1 \\
\hline \multicolumn{9}{|l|}{ Formicidae } \\
\hline Atta mexicana & $\mathrm{T}$ & 1 & 1.0 & 1 & 2.1 & 0.03 & $<0.1$ & 1.1 \\
\hline
\end{tabular}


Table 2. Continued.

\begin{tabular}{|c|c|c|c|c|c|c|c|c|}
\hline $\begin{array}{l}\text { Taxonomic Class/ } \\
\text { Prey category }\end{array}$ & Prey type & $N$ & $N \%$ & $F$ & $F \%$ & $V$ & $V \%$ & $I$ \\
\hline \multicolumn{9}{|l|}{ Lepidoptera } \\
\hline Unidentified (larvae) & $\mathrm{T}$ & 2 & 2.1 & 2 & 4.2 & 0.12 & 0.2 & 2.1 \\
\hline Odonata & & 7 & 7.3 & 6 & 12.5 & 2.22 & 3.1 & 7.6 \\
\hline \multicolumn{9}{|l|}{ Coenagrionidae } \\
\hline Argia sp. & $\mathrm{T}$ & 2 & 2.1 & 2 & 4.2 & 0.09 & 0.1 & 2.1 \\
\hline Libellulidae & $\mathrm{T}$ & 2 & 2.1 & 1 & 2.1 & 0.48 & 0.7 & 1.6 \\
\hline Unidentified (adult) & $\mathrm{T}$ & 2 & 2.1 & 2 & 4.2 & 1.38 & 2.0 & 2.7 \\
\hline Unidentified (nymph) & A & 1 & 1.0 & 1 & 2.1 & 0.27 & 0.4 & 1.2 \\
\hline \multicolumn{9}{|l|}{ Orthoptera } \\
\hline Unidentified & $\mathrm{T}$ & 4 & 4.2 & 3 & 6.3 & 6.76 & 9.6 & 6.7 \\
\hline \multicolumn{9}{|l|}{ Crustacea } \\
\hline \multicolumn{9}{|l|}{ Isopoda } \\
\hline Armadillidiidae & $\mathrm{T}$ & 2 & 2.1 & 1 & 2.1 & 0.11 & 0.2 & 1.4 \\
\hline \multicolumn{9}{|l|}{ VERTEBRATES } \\
\hline \multicolumn{9}{|l|}{ Amphibia } \\
\hline \multicolumn{9}{|l|}{ Ranidae } \\
\hline Lithobates sp. (larvae) & A & 1 & 1.0 & 1 & 2.1 & 0.91 & 1.3 & 1.5 \\
\hline Actinopterygii (Fishes) & & 35 & 36.5 & 24 & 50.1 & 40.43 & 57.3 & 48.0 \\
\hline Cyprinodontiformes & & 29 & 30.2 & 21 & 43.8 & 26.32 & 37.3 & 37.1 \\
\hline \multicolumn{9}{|l|}{ Goodeidae } \\
\hline Chapalichthys encaustus* & A & 1 & 1.0 & 1 & 2.1 & 0.07 & 0.1 & 1.1 \\
\hline Goodea atripinnis & A & 1 & 1.0 & 1 & 2.1 & 3.95 & 5.6 & 2.9 \\
\hline Unidentified & A & 3 & 3.1 & 3 & 6.3 & 4.51 & 6.4 & 5.3 \\
\hline \multicolumn{9}{|l|}{ Poeciliidae } \\
\hline Poecilia sp.** & A & 7 & 7.3 & 6 & 12.5 & 12.34 & 17.5 & 12.4 \\
\hline Poeciliopsis infans & A & 3 & 3.1 & 3 & 6.3 & 0.38 & 0.5 & 3.3 \\
\hline Non-identified & A & 14 & 14.6 & 9 & 18.8 & 5.07 & 7.2 & 13.5 \\
\hline Perciformes & & 6 & 6.3 & 3 & 6.3 & 14.11 & 20.0 & 10.8 \\
\hline \multicolumn{9}{|l|}{ Cichlidae } \\
\hline Oreochromis sp.** & A & 5 & 5.2 & 2 & 4.2 & 12.91 & 18.3 & 9.2 \\
\hline Non-identified & A & 1 & 1.0 & 1 & 2.1 & 1.20 & 1.7 & 1.6 \\
\hline Aquatic preys (A) & - & 42 & 43.8 & 29 & 60.4 & 44.79 & 63.5 & 55.9 \\
\hline Terrestrial preys $(\mathrm{T})$ & - & 54 & 56.2 & 24 & 50.0 & 13.85 & 19.6 & 42.0 \\
\hline Plant material & - & - & - & 6 & 12.5 & 1.86 & 2.6 & - \\
\hline Undetermined remains & - & - & - & 25 & 52.1 & 10.07 & 14.3 & - \\
\hline Totals & - & 96 & 100 & 48 & 100 & 70.57 & 100 & - \\
\hline
\end{tabular}




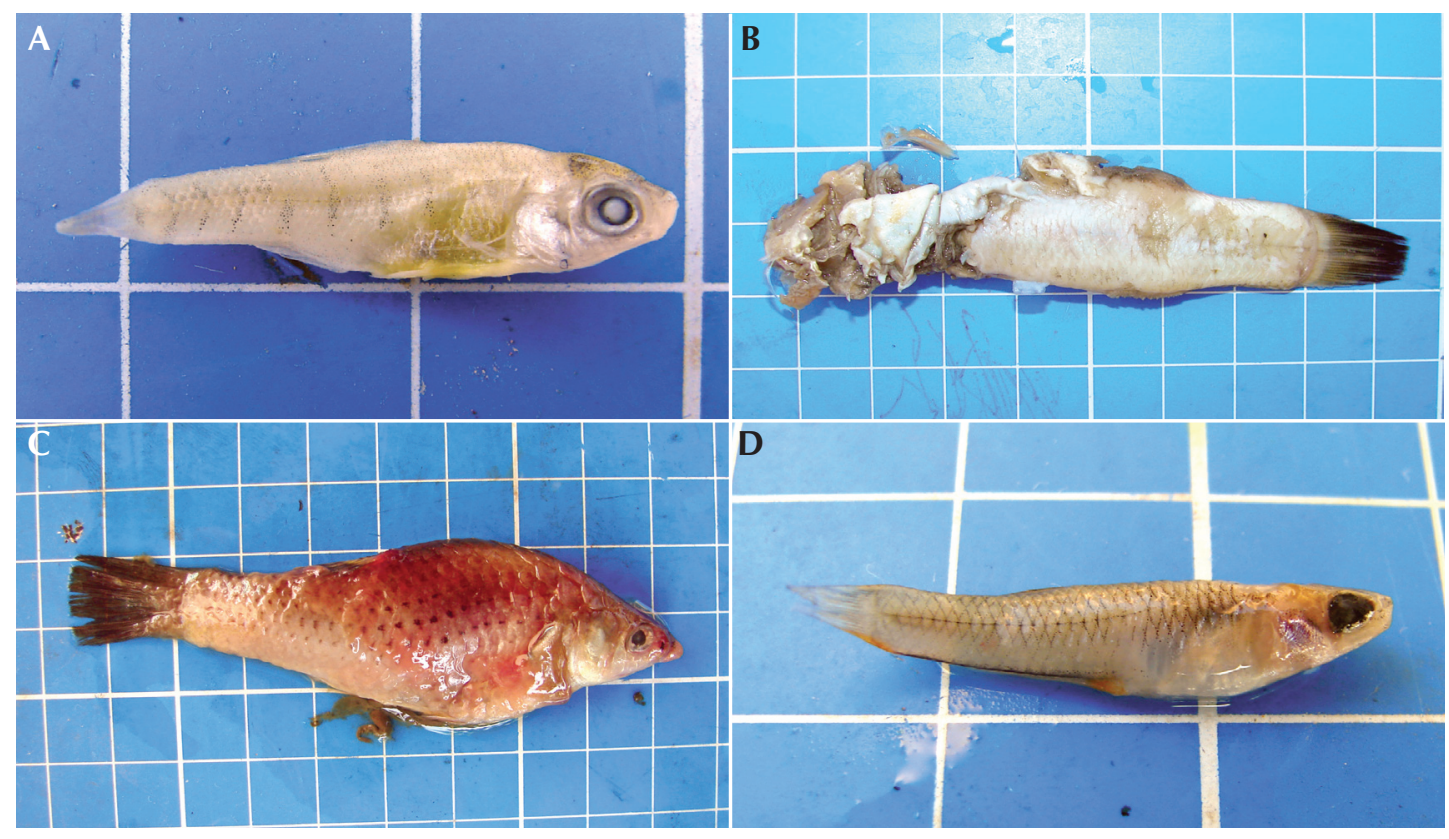

Figure 2. Some fish samples extracted from the stomach contents of Lithobates megapoda. Goodeidae: (A) Chapalichthys encaustus, (B) Goodea atripinnis. Poecilidae: (C) Poecilia sp., (D) Poeciliopsis infans. Scale: each square $=1 \mathrm{~cm}^{2}$.
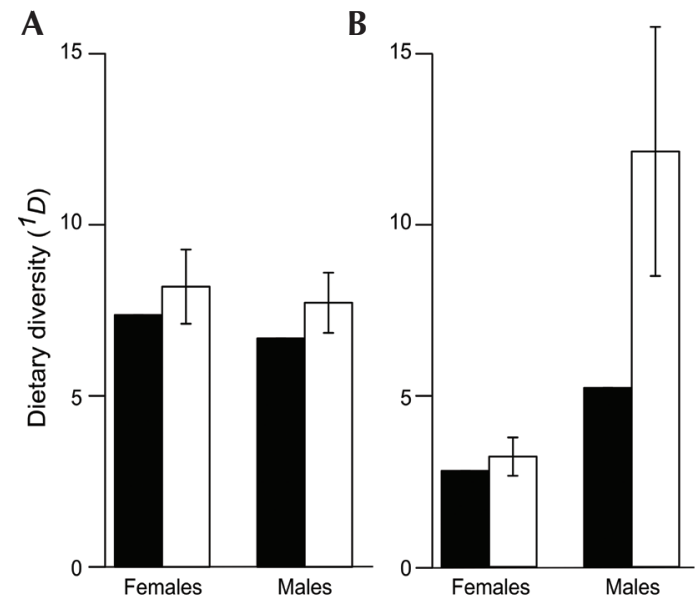

Figure 3. Dietary diversity $\left({ }^{1} \mathrm{D}\right)$ with abundance $(\mathbf{A})$, and prey volume (B) in males and females of Lithobates megapoda. Dark bars = observed dietary diversity; white bars = estimated dietary diversity. Error bars are 95\% confidence intervals.
We found correlation between the average of prey volume and SVL $\left(\mathrm{F}_{1,40}=60.009 ; p<0.001\right)$, which was different between the sexes $\left(\mathrm{F}_{1,38}=\right.$ 54.1; $p<0.001$ ), with a negative trend in males and a positive trend in females (Figure 4A). We found differences between total prey volume per $\operatorname{SVL}\left(\mathrm{F}_{1,46}=57.61 ; p<0.001\right)$ and $\operatorname{sex}\left(\mathrm{F}_{1,45}=\right.$ 46.98; $\mathrm{p}<0.001$ ), with females presenting larger volumes of prey in their stomach than males of similar size (Figure 4B). No differences were found in the correlation of number of prey and $\operatorname{SVL}\left(\mathrm{F}_{1,40}=52.38 ; p=0.54\right)$ and $\operatorname{sex}\left(\mathrm{F}_{1,39}=\right.$ 50.77; $p=0.2$ ) (Figure 4C).

\section{Discussion}

The results of this study indicate that the diet of Lithobates megapoda on the shore of Lake Chapala, during the rainy season, is composed of a wide variety of prey, as occurs with other 
Barragán-Ramírez et al.

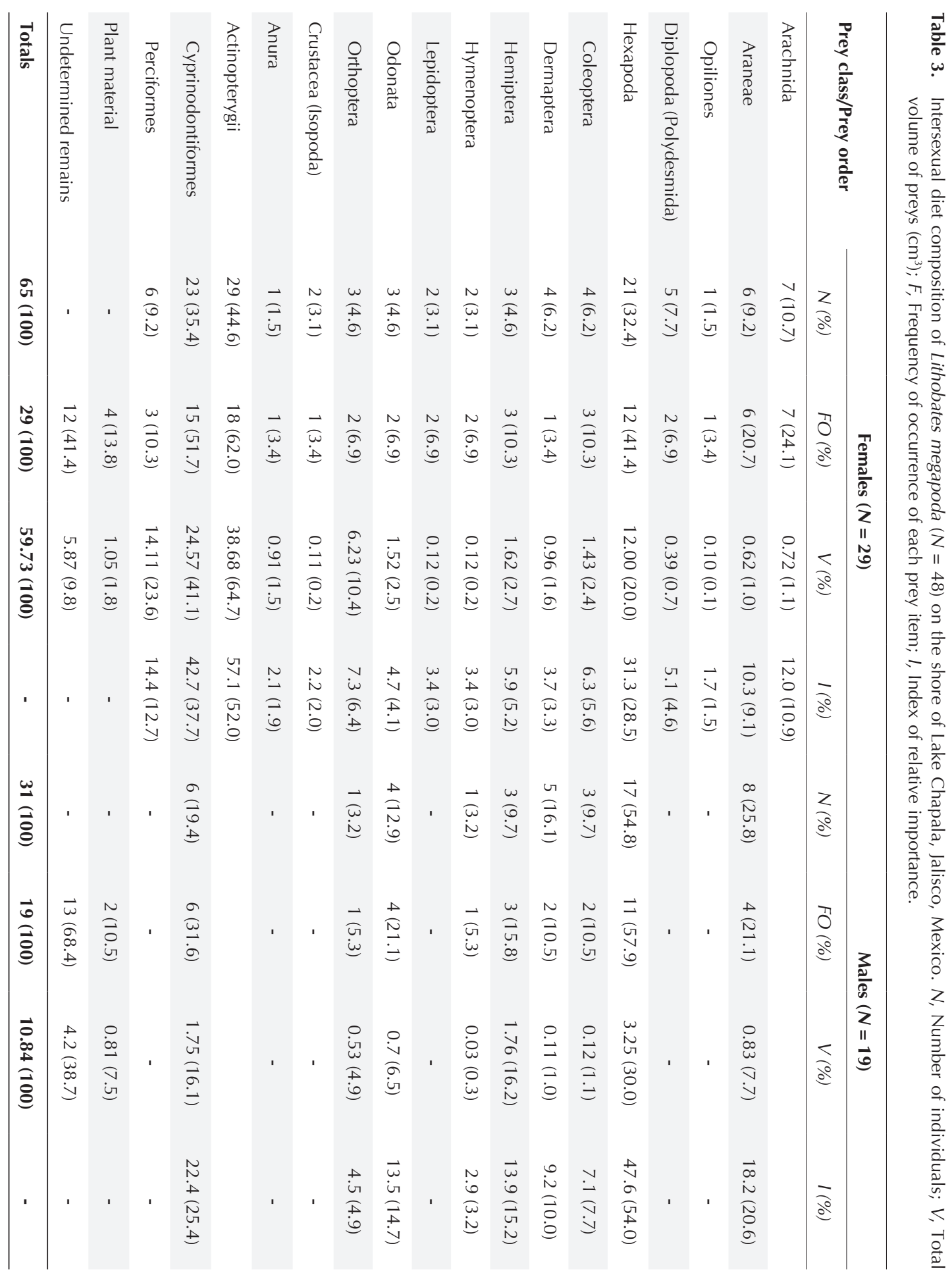



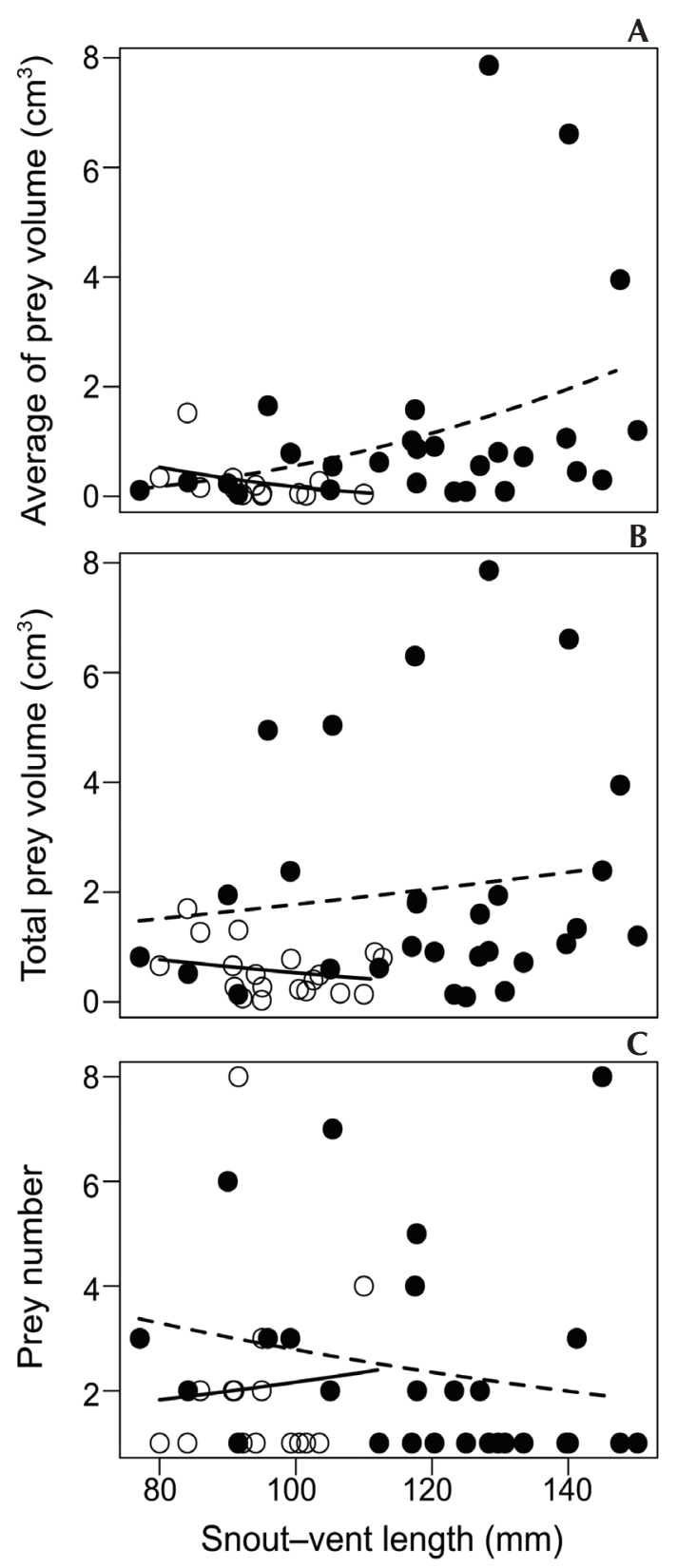

Figure 4. Correlation between snout-vent length (SVL) of adults Lithobates megapoda and (A) average of prey volume, (B) total prey volume, and (C) number of prey consumed. Open circles and trend lines represent males and solid circles and dashed lines represent females. ranids that are considered generalist-opportunistic predators (Hirai and Matsui 1999, Wu et al. 2005). However, L. megapoda shows a preference for fish consumption, which according to the relative importance index is the most valuable prey category in the diet of this frog. Because its diet includes both aquatic and terrestrial organisms, this frog species represents a link between aquatic and terrestrial communities where it plays an important role in the food web.

Unlike other frogs that can feed on fish, Lithobates megapoda shows a high percentage of frequency of fish consumption $(\sim 50 \%)$, which is above that reported in other ranids in Mexico (with less than 5\%) as L. berlandieri (Baird, 1859) and L. johni (Blair, 1965) (Hernández-Austria et al. 2019), L. brownorum (Sanders, 1973) (RamírezBautista and Lemos-Espinal 2004), L. vaillanti (Brocchi, 1877) (Ramirez et al. 1998, RamírezBautista and Lemos-Espinal 2004, Luría-Manzano and Ramírez-Bautista 2019), and L. zweifeli (Hillis, Frost, and Webb, 1984) (Mendoza-Estrada et al. 2008). We need further studies to evaluate the high contribution of fish as food source for $L$. megapoda. It can be related to different factors, such as opportunistic habits (Premo and Atmowidjojo 1987, Hirai and Matsui 1999, Dietl et al. 2009), digestibility (Secor et al. 2007) promoting greater nutritional contribution (Das 1996), especially during reproductive period due to the energy expenditure involved (Lamb 1984, Ryser 1989), or high availability in the habitat (Parker and Goldstein 2004, López et al. 2009).

We recorded at least five species of fishes in the diet of L. megapoda, three are native to Lake Chapala: Chapalichthys encaustus (Jordan and Snyder, 1899) (endemic to Lake Chapala basin), Goodea atripinnis Jordan, 1880, and Poeciliopsis infans (Woolman, 1894). The other two are nonnative species, Poecilia sp. and Oreochromis sp., the latter known as "Tilapia" and native to Africa (Miller et al. 2009, Moncayo-Estrada et al. 2012). All these fishes are frequent in areas with aquatic vegetation (Miller et al. 2009), where $L$. megapoda is commonly found. Aquatic prey, which were more valuable than terrestrial prey 
according to the relative importance index, included along with fish, organisms such as belostomatids, damselfly nymph, and a tadpole, indicating the ability to capture prey underwater, as already suggested for other ranids (Stewart and Sandison 1972). The presence of a congeneric tadpole in one of the stomachs indicates the occurrence of cannibalism, reinforcing the opportunistic behavior of this frog. Similar cases have been widely reported in other ranids (e.g., Mendoza-Estrada et al. 2008, Silva et al. 2009, Alvarez 2013).

The presence of terrestrial preys in the diet of L. megapoda suggests that individuals forage near the lake margins, a behavior also documented to other ranids (e.g., Ramírez-Bautista and LemosEspinal 2004). The floating and aquatic vegetation constitute an important habitat for different invertebrates, like spiders and dragonflies (Akamatsu et al. 2004), which were important prey in the diet of L. megapoda after fish.

Considering the low percentage of occurrence and volume in the stomachs, the ingestion of plant material is probably accidental, as reported for other ranids (Hedeen 1972, Kramek 1972, Mendoza-Estrada et al. 2008).

Dietary diversity based on abundance seems similar between sexes, as has happened in other species of anurans (e.g., Hirai and Matsui 1999, Silva et al. 2009, Luría-Manzano and GutiérrezMayén 2014), but females seem to consume prey with a wider volume range, usually larger ones when compared to males of similar size. Unfortunately, we did not access prey availability or sex or size variation among the three different collection sites within the Lake Chapala, and the results should be considered cautiously, since sample biases are possible. The effect of sex and size of the frogs may suggest larger intraspecific competition between large mature males and smaller young females. Additionally, foraging behavior of males and females may vary. An interesting future approach would be to compare the diet composition of adults out of the rainy season (which is also the breeding season) to see if differences remain.

\section{Acknowledgments}

We thank Agustín Camacho-Rodríguez for its valuable support in the fish identification and the CONACyT for support of the PhD scholarship to J. L. Barragán-Ramírez. We are grateful to the anonymous reviewers for their comments and suggestions to improve the manuscript.

\section{References}

Agudelo-Cantero, G. A., R. S. Castaño-Valencia, F. CastroHerrera, L. Fierro-Pérez, and H. Asencio-Santofimio. 2015. Diet of the Blue-bellied poison frog Andinobates minutus (Anura: Dendrobatidae) in two populations from the Colombian Pacific. Journal of Herpetology 49: 452-461.

Akamatsu, F., H. Toda, and T. Okino. 2004. Food source of riparian spiders analyzed by using stable isotope ratios. Ecological Research 19: 655-662

Alvarez, J. A. 2013. Rana draytonii (California Red-legged Frog). Cannibalism. Herpetological Review 44: 126-127.

Araujo-Vieira, K., U. Gonçalves, J. G. Santos, T. GomesFerreira, and G. O. Skuk. 2018. Feeding habits of the bromeligenous treefrog Phyllodytes edelmoi Peixoto, Caramaschi \& Freire, 2003 (Anura: Hylidae) from the State of Alagoas, Northeastern Brazil. Cuadernos de Herpetología 32: 5-13.

Barragán-Ramírez, J. L., J. L. Navarrete-Heredia, and E. Pineda. 2017. La rana patona, un coloso en la ribera del lago de Chapala. CONABIO. Biodiversitas 132: 7-11.

Berazategui, M., A. Camargo, and R. Maneyro. 2007. Environmental and seasonal variation in the diet of Elachistocleis bicolor (Guérin-Méneville 1838) (Anura: Microhylidae) from northern Uruguay. Zoological Science 24: 225-231.

Biavati, G. M., H. C. Wiederhecker, and G. R. Colli. 2004. Diet of Epipedobates flavopictus (Anura: Dendrobatidae) in a neotropical savanna. Journal of Herpetology 38: $510-518$.

Bonansea, M. I. and M. Vaira. 2007. Geographic variation of the diet of Melanophryniscus rubriventris (Anura: Bufonidae) in northwestern Argentina. Journal of Herpetology 41: 231-236.

CEA Jalisco. 2020. Lago de Chapala. Comisión Estatal del Agua Jalisco [en línea]. Electronic Database accessible at http:ceajalisco.gob.mx/contenido/Chapala/. Accessed on 08 March 2020. 
Coronado, R. and A. Márquez. 1977. Introducción a la Entomología: morfología y taxonomía de los insectos. Mexico. Editorial Limusa. 282 pp.

Das, I. 1996. Folivory and seasonal changes in diet in Rana hexadactyla (Anura: Ranidae). Journal of Zoology 238: 785-794.

Dietl, J., W. Engels, and M. Solé. 2009. Diet and feeding behaviour of the leaf-litter frog Ischnocnema henselii (Anura: Brachycephalidae) in Araucaria rain forests on the Serra Geral of Rio Grande do Sul, Brazil. Journal of Natural History 43: 1473-1483.

Duellman, W. E. and L. Trueb. 1994. Biology of Amphibians. Baltimore and London. Johns Hopkins University Press. $670 \mathrm{pp}$.

Duré, M. I., A. I. Kehr, and E. F. Schaefer. 2009. Niche overlap and resource partitioning among five sympatric bufonids (Anura, Bufonidae) from northeastern Argentina. Phyllomedusa 8: 27-39.

Filonov, A. E., I. E. Tereshchenko, and C. O. Monzón. 2001. Hydro-meteorology of Lake Chapala. Pp. 151-182 in A. M. Hansen and M. van Afferden (eds.), The LermaChapala Watershed: Evaluation and Management. New York. Kluwer Academic/Plenum Publishers.

Fulgence, T. R., D. A. Martin, H. Kreft, F. M. Ratsoavina, and F. M. Andrianarimisa. 2020. Spider traps amphibian in northeastern Madagascar. Ecology and Evolution 11: $682-687$.

Gibbons, J. W., C. T. Winne, D. E. Scott, J. D. Willson, X. Glaudas, K. M. Andrews, B. D. Todd, L. A. Fedewa, L. Wilkinson, R. N. Tsaliagos, S. J. Harper, J. L. Greene, T. D. Tuberville, B. S. Metts, M. E. Dorcas, J. P. Nestor, C. A. Young, T. Akre, R. N. Reed, K. A. Uhlmann, J. Norman, D. A. Croshaw, C. Hagen, and B. B. Rothermel. 2006. Remarkable amphibian biomass and abundance in an isolated wetland: implications for wetland conservation. Conservation Biology 20: $1457-$ 1465.

Hedeen, S. E. 1972. Food and feeding behavior of the Mink Frog, Rana septentrionalis Baird, in Minnesota. American Midland Naturalist 88: 291-300.

Hernández-Austria, R., R. Luría-Manzano, and A. RamírezBautista. 2019. Variation in feeding habits between two syntopic frog pecies (genus Lithobates) of a tropical habitat in the Atlantic versant of Mexico. Journal of Herpetology 53: 289-296.

Hirai, T. and M. Matsui. 1999. Feeding habits of the pond frog, Rana nigromaculata, inhabiting rice fields in Kyoto, Japan. Copeia 1999: 940-947.

Jost, L. 2006. Entropy and diversity. Oikos 113: 363-375,
IUCN SSC Amphibian Specialist Group. 2020. Lithobates megapoda. The IUCN Red List of Threatened Species 2020: e.T58662A53970952. https://dx.doi.org/10.2305/ IUCN.UK.2020-3.RLTS.T58662A53970952.en. Accessed on 08 June 2021.

Kramek, W. C. 1972. Food of the frog Rana septentrionalis in New York. Copeia 1972: 390-392.

Lamb, T. 1984. The influence of sex and breeding condition on microhabitat selection and diet in the Pig Frog Rana grylio. American Midland Naturalist 111: 311-318.

Lima, A. P. and W. E. Magnusson. 2000. Does foraging activity change with ontogeny? An assessment for six sympatric species of postmetamorphic litter anurans in Central Amazonia. Journal of Herpetology 34: 192200 .

Liner, E. A. and G. Casas-Andreu. 2008. Standard Spanish, English and scientific names of the amphibians and reptiles of Mexico. Herpetological Circular 38: 1-162.

Lopes, M. S., R. S. Bovendorp, G. J. Moraes, A. R. Percequillo, and J. Bertoluci. 2017. Diversity of ants and mites in the diet of the Brazilian frog Chiasmocleis leucosticta (Anura: Microhylidae). Biota Neotropica 17: $1-5$.

López, J. A., P. A. Scarabotti, M. C. Medrano, and R. Ghirardi. 2009. Is the red spotted green frog Hypsiboas punctatus (Anura: Hylidae) selecting its preys? The importance of prey availability. Revista de Biología Tropical 57: 847-857.

Luría-Manzano, R. and G. Gutiérrez-Mayén. 2014. Reproduction and diet of Hyla euphorbiacea (Anura: Hylidae) in a pine-oak forest of southeastern Puebla, Mexico. Vertebrate Zoology 64: 207-213.

Luría-Manzano, R. and A. Ramírez-Bautista. 2017. Diet comparison between rainforest and cave populations of Craugastor alfredi (Anura: Craugastoridae): does diet vary in contrasting habitats? Journal of Natural History 51: 2345-2354.

Luría-Manzano, R. and A. Ramírez-Bautista. 2019. Dietary composition and selection in the stream-breeding anuran assemblage from a tropical wet forest in eastern Mexico. Acta Oecologica 98: 36-44.

Magnusson, W. E., A. P. Lima, W. Alves Silva, and M. Carmozina de Araújo. 2003. Use of geometric forms to estimate volume of invertebrates in ecological studies of dietary overlap. Copeia 2003: 13-19.

Maneyro, R., D. E. Naya, I. Rosa, A. Canavero and A. Camargo. 2004. Diet of the South American frog Leptodactylus ocellatus (Anura, Leptodactylidae) in Uruguay. Iheringia, Série Zoologia 94: 57-61. 
Mendoza-Estrada, L. J., R. Lara-López, and R. CastroFranco. 2008. Dieta de Lithobates zweifeli Hillis, Frost y Webb 1984 (Anura: Ranidae) en un río estacional del centro de México. Acta Zoológica Mexicana (n.s.) 24: $169-197$.

Miller, R. R., W. L. Minckley, and S. M. Norris. 2009. Peces dulceacuícolas de México. Comisión Nacional para el Conocimiento y Uso de la Biodiversidad/ El Colegio de la Frontera Sur/Sociedad Ictiológica Mexicana, A. C. / Desert Fishes Council, México, D. F. 559 pp.

Moncayo-Estrada, R., J. Lyons, C. Escalera-Gallardo, and O. T. Lind. 2012. Long-term change in the biotic integrity of a shallow tropical lake: A decadal analysis of the Lake Chapala fish community. Lake and Reservoir Management 28: 92-104.

Nuñez-Escalante, R. and D. Garro-Acuña. 2021. Tailless Whip Scorpions (Paraphrynus laevifrons) preying on metamorphic juvenile Gliding Leaf Frogs (Agalychnis spurrelli) in Costa Rica. Reptiles \& Amphibians 28: 9697.

Parker, M. L. and M. I. Goldstein. 2004. Diet of the Rio Grande leopard frog (Rana berlandieri) in Texas. Journal of Herpetology 38: 127-130.

Premo, D. B. and A. H. Atmowidjojo. 1987. Dietary patterns of the "crab-eating frog", Rana cancrivora, in West Java. Herpetologica 43: 1-6.

R Core Team. 2017. R: A language and environment for statistical computing (Computer software). R Foundation for Statistical Computing, Vienna, Austria. Version 3.1.2. URL: http://www.R-project.org/.

Ramirez, J., R. C. Vogt, and J. L. Villarreal-Benitez. 1998. Population biology of a neotropical frog (Rana vaillanti). Journal of Herpetology 32: 338-344.

Ramírez-Bautista, A. and J. A. Lemos-Espinal. 2004. Diets of two syntopic populations of frogs, Rana vaillanti and Rana brownorum, from a tropical rain forest in southern Veracruz, Mexico. Southwestern Naturalist 49: 316320 .

Ryser, J. 1989. Weight loss, reproductive output, and the cost of reproduction in the common frog, Rana temporaria. Oecologia 78: 264-268.

Secor, S. M., J. A. Wooten, and C. L. Cox. 2007. Effects of meal size, meal type, and body temperature on the specific dynamic action of anurans. Journal of Comparative Physiology B 177: 165-182.

SEMARNAT (Secretaría de Medio Ambiente y Recursos Naturales). 2010. Norma Oficial Mexicana NOM-059-
SEMARNAT-2010. Protección ambiental de especies nativas de México de flora y fauna silvestres. Categorías de riesgo y especificaciones para su inclusión, exclusión o cambio. Lista de especies en riesgo. Diario Oficial de la Federación (Segunda Sección), 30 de diciembre de 210, Ciudad de México, Mexico. 77 pp.

Shannon, C. E. and W. Weaver. 1949. The Mathematical Theory of Communication. Urbana, Illinois. University of Illinois Press. 144 pp.

Silva, E. T., E. P. Reis, R. N. Feio, and O. P. Ribeiro Filho. 2009. Diet of the invasive frog Lithobates catesbeianus (Shaw, 1802) (Anura: Ranidae) in Viçosa, Minas Gerais State, Brazil. South American Journal of Herpetology 4: $286-294$

Solé, M. and D. Rödder. 2010. Dietary assessments of adult amphibians. Pp. 211-254 in C. K. Dodd (eds.), Amphibian Ecology and Conservation. A Handbook of Techniques. Oxford. Oxford University Press.

Stebbins, R. C. and N. W. Cohen. 1995. A Natural History of Amphibians. Princeton. Princeton University Press. 316 pp.

Stewart, M. M. and P. Sandison. 1972. Comparative food habits of sympatric Mink Frogs, Bullfrogs, and Green Frogs. Journal of Herpetology 6: 241-244.

Taylor, E. H. and H. M. Smith. 1945. Summary of the collections of amphibians made in Mexico under the Walter Rathbone Bacon Traveling Scholarship. Proceedings of the United States National Museum 95: 521-613.

Triplehorn, C. A. and N. F. Johnson. 2005. Borror and Delong's Introduction to the Study of Insects. $7^{\text {th }}$ edition. Thomson Brooks/Cole, USA. 864 pp.

Webb, R. G. 1996. A systematic review of the Mexican frog Rana megapoda Taylor (Anura: Ranidae). Southwestern Naturalist 41: 35-42.

Whitfield, S. M. and M. A. Donnelly. 2006. Ontogenetic and seasonal variation in the diets of a Costa Rican leaf-litter herpetofauna. Journal of Tropical Ecology 22: 409417.

Wu, Z., Y. Li, Y. Wang, and M. J. Adams. 2005. Diet of introduced bullfrogs (Rana catesbeiana): predation on and diet overlap with native frogs on Daishan Island, China. Journal of Herpetology 39: 668-674.

Zahl, S. 1977. Jackknifing an index of diversity. Ecology 58: 907-91.

Editor: Vanessa K. Verdade 